the Freed paper "so important that it went through intense vetting".

Clashes between academics and conservation managers are not uncommon - but rarely do relations become quite so strained. Since 2006, Freed has not been granted permits to work in the reserve because of the ongoing disputes. When Freed asked graduate students to follow the birds instead, Richard Waas, the refuge manager at the time, demanded that they stop, saying they did not have the necessary permits. Refuge officials then threatened to call law-enforcement rangers.

\section{Blocked projects}

Dawn Reding, now a PhD candidate at Iowa State University in Ames, is one of several students who have been affected by the situation. She says that being refused permission for her akepa study in 2004 delayed her master's project by a year; "I was really upset," she says.

Matthew Medeiros, a native Hawaiian and undergraduate student, says that his proposal to use artificial nests to study akepa was rejected because of the conflict. "If you were associated with [Freed], Jeffrey blocked everything," says Medeiros, who is now a graduate student at the University of Missouri in St Louis.

Jeffrey says the student cases have been "blown out of proportion".

For years Freed and refuge officials also argued over how best to assess blood samples from akepa to test them for malaria. The fight dragged on for so long that key work was approved only after Freed's federal grant for the work had expired.

Gary Ostrander, the vice-chancellor for research at the University of Hawaii, says he hopes the university can "continue to work collectively" with the refuge.

Rex Dalton

opposed the proposal, arguing that it was prejudicial to basic scientists. "It's a terrible idea," said Thomas Kelly, director of the SloanKettering Institute in New York City. "It invites gaming the system. You check that [human subjects] box and get $50 \%$ more space."

Mary-Claire King, a geneticist at the University of Washington in Seattle, argued that applications involving human subjects do not require any more space than those for "flies, worms, mice, bacteria or yeast".

The decision of whether or not to implement the change ultimately rests with Kington, who says it will be made "pretty quickly". Whatever the outcome, the new rules won't come into effect until 2010.

Meredith Wadman

\title{
Plant hormone study pulled
}

Two years ago, three papers ${ }^{1-3}$ made a splash in the plant biology world by identifying protein receptors for abscisic acid (ABA), a key hormone in plant physiology. This week, Nature is retracting one of those papers ${ }^{1}$ after reports that the work could not be replicated. The two other papers still stand, although one $\mathrm{e}^{3}$ has been questioned by several researchers ${ }^{4-7}$.

The retraction is a setback in the search to find receptors for $\mathrm{ABA}$, a notoriously difficult task. ABA responds to environmental stresses such as drought, and is an alluring target for agricultural companies hoping to produce drought-resistant crops.

The retraction in Nature comes from the team that did the work, led by Robert Hill of the University of Manitoba in Winnipeg, Canada. Hill says the experiments were carried out by postdoc Fawzi Razem, who has since left the university; Hill says he does not know for where. A Nature reporter was unable to contact Razem.

John Danakas, director of public affairs for the university, says that he cannot comment on this case in particular, but says that "normally when there are problems with research results being reproducible, there would be an investigation at the senior administrative level".

According to the search tool Scopus, Hill's paper has been cited 120 times, and is the most highly cited study among the 95 results for 'abscisic acid receptor' in the past three years.

Hill says he moved on from the project after the paper was published, but started to realize something might be wrong after some of his postdocs returned to it in late 2007 and could not replicate the results. He was also contacted by Catherine Day of the University of Otago in Dunedin, New Zealand, who could not repeat the work either. "I suspect it has hurt a lot of people," he says. "It certainly hurt my lab quite significantly. I certainly feel very bad about it and am very apologetic to the community."

According to Hill, his team interpreted an experiment as showing that $\mathrm{ABA}$ broke up a binding interaction between the receptor candidate FCA, involved in flowering, and another protein, FY, because ABA bound better to FCA than did FY. In fact, he says, the FY protein was not properly prepared, and probably never bound to FCA at all. Another experiment purporting to show direct binding between FCA and ABA was miscalculated and, says Hill, "the assay procedure is also suspect".

Some plant-hormone specialists had wondered about the results of this and the other papers from the beginning, as they did not fit with the rest of what was known about ABA. The studies all used in vitro biochemical techniques to identify the receptor, rather than the more usual method of identifying and cloning mutated genes before determining if they coded for a receptor.

"There was nothing really wrong with the paper; you couldn't say 'this gel isn't any good', says Peter McCourt, an ABA specialist at the University of Toronto, Canada. But "none of it linked up with any of the genetics that had been done in the previous 20 years".

The other papers identify similarly unexpected receptors. "People who are doing this are sceptical and are not putting all their money on these findings," says Jianhua Zhang, who works on other aspects of ABA at Hong Kong Baptist University.

Dayblames the problems on tricky assays. "I think they've just had a bad start. These proteins are difficult to work with." McCourt thinks such experiments might be too complicated to pursue. Collecting proteins from plant cells for binding studies is easier said than done, he says, as plant cells are particularly crowded, complex places.

Meanwhile, Hill says, "I just want to get this behind me."

Emma Marris

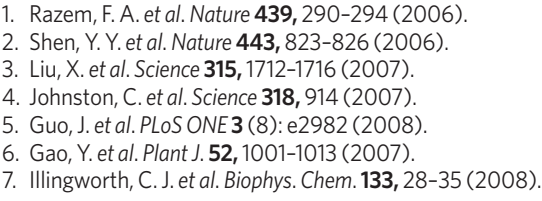

